\title{
On the Rationality and Ethics of Nuclear Deterrence ${ }^{1}$
}

\author{
Jean-Pierre Dupuy \\ Stanford University, USA
}

\begin{abstract}
Beginning with a brief outline of the ethical contradictions inherent to nuclear deterrence, this paper highlights the flaws of commonly acknowledged theories regarding the efficiency of nuclear threats. The paper concludes that a theory of "existential deterrence" is the only way to somewhat safeguard the rationality of nuclear deterrence. The backbone of this contention is a metaphysics of time according to which the actual and the potential coincide, and future events necessarily occur. In that framework nuclear deterrence appears to be an ethical abomination.
\end{abstract}

\section{Keywords}

David K. Lewis; Ethics; Mutually Assured Destruction; Nuclear Deterrence; Rationality.

DOI: 10.22618/TP.PJCV.20215.1.139008

The PJCV Journal is published by Trivent Publishing

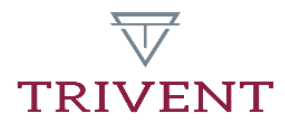

\footnotetext{
1 The original French version of this paper was published under the title "Rationalité et éthique de la dissuasion nucléaire" in the journal Préventique (September 2019). Courtesy of the editors of Préventique and Jean-Pierre Dupuy for the translation rights.

This is an Open Access article distributed in accordance with the Creative Commons Attribution Non Commercial (CC$B Y-N C$-ND 4.0) license, which permits others to copy or share the article, provided original work is properly cited and that this is not done for commercial purposes. Users may not remix, transform, or build upon the material and may not distribute the modified material (bttp:/ / creativecommons.org/ licenses/by-nc/4.0/)
} 


\title{
On the Rationality and Ethics of Nuclear Deterrence ${ }^{1}$
}

\author{
Jean-Pierre Dupuy \\ Stanford University, USA
}

\begin{abstract}
Beginning with a brief outline of the ethical contradictions inherent to nuclear deterrence, this paper highlights the flaws of commonly acknowledged theories regarding the efficiency of nuclear threats. The paper concludes that a theory of "existential deterrence" is the only way to somewhat safeguard the rationality of nuclear deterrence. The backbone of this contention is a metaphysics of time according to which the actual and the potential coincide, and future events necessarily occur. In that framework nuclear deterrence appears to be an ethical abomination.
\end{abstract}

\section{Keywords}

David K. Lewis; Ethics; Mutually Assured Destruction; Nuclear Deterrence; Rationality.

In a previous article, ${ }^{2} \mathrm{I}$ had assessed the likelihood of the accidental start of a nuclear war under the current geopolitical circumstances and defended the theory that it was stronger than during the worst moments of the Cold War. I was drawing on the analyses contained in a recent book of mine ${ }^{3}$ whose main focus was the examination of nuclear weapons from the double standpoint of rationality and of ethics. This is the matter that I would like to address here.

The rationality issue of possessing nuclear weapons boils down to that of their effectiveness as deterrents. Indeed, in principle, the purpose of these weapons is neither to attack, nor to defend oneself, but simply to deter others from using them. Has deterrence been effective? The unsophisticated answer consists of remarking that there has been no nuclear apocalypse since 1945. The one provided by Robert McNamara, who was Secretary of Defense under Presidents Kennedy and Johnson, is just as succinct: we have been saved by chance. ${ }^{4}$ We shall see that this is, in fact, a very difficult matter.

But what has ethics got to do with this? For serious people who call themselves realists, one does not waste time on inconsequential issues when the survival of the world is at stake. However, in a democracy, when armed forces are legitimate, they draw a stance that eludes

\footnotetext{
${ }_{1}^{1}$ The original French version of this paper was published under the title "Rationalité et éthique de la dissuasion nucléaire" in the journal Préventique (September 2019). Courtesy of the editors of Préventique and Jean-Pierre Dupuy for the translation rights.

${ }^{2}$ Jean-Pierre Dupuy, "Le péril atomique et les raisons de notre insouciance," Préventique 166 (September 2019).

${ }^{3}$ Jean-Pierre Dupuy, La Guerre qui ne peut pas avoir lieu. Essai de métaphysique nucléaire (Paris: Desclée de Brouwer, 2019).

4 The Fog of War: Eleven Lessons from the Life of Robert S. McNamara, directed by Errol Morris (USA: Sony Pictures Classics, 2003).
} 
the sterile opposition between realism and pacifism. Now, I think I have shown that, if one manages to substantiate the effectiveness of deterrence, one must conclude that the mere possession of nuclear weapons is a moral abomination. Rationality and ethics are closely intertwined matters.

I shall begin with ethics. Moral philosophy is torn between two great poles, namely consequentialism and deontology. ${ }^{5}$ This is the case that lies at the origin of the conflict opposing them: is it allowed to put to death someone whom we know to be innocent of a crime that enraged a crowd, if this sacrifice, calming down the pack, avoided the death of several equally innocent people? Consequentialism, being only interested in the consequences, answers that, more than being just allowed, this is what must occur; deontology, appraising acts from the viewpoint of their compliance with imperatives possessed of an absolute value — that is, independent of the value of consequences (in this case, the "thou shalt not kill") - answers in the negative.

The ethics of nuclear deterrence takes the conflict between these two sources of common morality to the extreme. Is it moral for the United States to practice deterrence towards North Korea? This implies "threatening to kill" a million North Korean civilians, not counting collateral damage in South Korea, so as to deter the former's country from being the first to attack, taking South Korea, the American island of Guam, or even Japan, as its targets. If, as contended by my colleague from Stanford, Scott Sagan, ${ }^{6}$ this is the first, or even the only option available in order to secure peace, consequentialism concludes that:

(1) Forming the intention to kill a million North Korean citizens is right.

As for deontology, it states the following:

(2) Killing a million people, whomever they might be, is wrong.

What prevents (1) and (2) from being downright contradictory is that on one side there is an intention, and on the other side there is an act. In order to reveal the contradiction, we must make use of a principle inherited from the ethics of intentionality, which goes as follows:

(3) If doing $x$ is wrong, then forming the intention to do $x$ is wrong, whatever $x$ may be. $^{7}$

Just like the matter of sacrifice, which undoubtedly dates back to the foundations of humanity, nuclear weapons put morality deeply at odds with itself. As I have previously said, realists cannot prevent deterrence from being tainted with illegitimacy, even while claiming that they could not care less about this.

However, it must be acknowledged that this argument has a weak point, namely the principle (3). This can be rejected or weakened, which is what the French doctrine does when stating that, if France forms the intention of liquidating up to sixty million nationals of a state that would attack its vital interests, this is precisely so that, thanks to deterrence, the circumstances conducive to its taking action won't be met. Specialists talk about a self-

\footnotetext{
5 This word is not to be understood in the sense used when talking about professional deontology. It designates a theory of duties, whose most important illustration can be found in Kant. See Immanuel Kant, The Metaphysics of Morals, $2^{\text {nd }}$ ed. (Cambridge: Cambridge University Press, 2017).

'See Scott D. Sagan, "The Korean Missile Crisis. Why Deterrence is Still the Best Option," Foreign Affairs (September 2017), https://www.foreignaffairs.com/articles/north-korea/2017-09-10/korean-missilecrisis (accessed February 9, 2020).

7 Philosopher Gregory Kavka dwelt on this paradox in his Moral Paradoxes of Nuclear Deterrence (Cambridge: Cambridge University Press, 2009).
} 
stultifying intention, an intention that one would not really intend to turn into an act, which names the enigma without elucidating it.

For this radical opposition between deontology and consequentialism to exist, nuclear deterrence must be effective, a crucial hypothesis that supports principle (1). Showing that such can be the case is a very arduous endeavor, involving some of the most difficult concepts of metaphysics. I fear that I might only be able to scratch the surface of things here.

Since no historical data allow us to settle the argument, we must resort to a priori reasoning. Two arguments have been put forward and discussed both by philosophers and by strategists, who concluded on the ineffectiveness of deterrence, throughout the Cold War. The most hotly debated was the non-credible nature of the deterrent threat. As long as the Nation-State that, should its vital interests be endangered, threatens to drag its opponent into a deadly and suicidal escalation, is endowed with a minimum amount of rationality when backed into a corner - for instance, after an initial strike that has destroyed part of its territory — it will not put its threat into execution. If it did, this would trigger an escalation that would go to the bitter end, that is, to their mutual annihilation, and, to top it all, to that of everyone around them. ${ }^{8}$ In order to choose that option, one would have to be insane. Therefore, the paradox lodged at the heart of nuclear deterrence is that the latter is only rational as long as it is based on a threat whose carrying out would be the ultimate irrationality.

This argument, concluding on the ineffectiveness of deterrence, is coupled with the following reasoning. Let us think about deterrence in general, for instance, about that represented by the criminal justice system. For it to be functional, it must not be hundred percent functional. Breaches are necessary so that everyone can see their cost. This is what is called the demonstration effect. In the case of nuclear weapons, this effect is non-existent: the potential attacker cannot access any empirical basis telling him how his enemy, were he the victim of a first nuclear strike, would react. For both of them, the first failure would be one too many.

Can one work around these two arguments and allege that nuclear deterrence is effective, in the sense that the mutual threat of retaliation is enough to prevent the outbreak of war? Here again, this can only happen by means of a theoretical counterargument. Now, the latter already exists, and it was given the name of "existential deterrence." The stratagem used by the theorists of this doctrine consists of dispensing with the threat, the intentions, the plans — in short, with the gist of military strategy. Some truly remarkable minds can be found among them: Bernard Brodie, nicknamed the "American Clausewitz," and who was the first great theorist of the Mutually Assured Destruction (MAD), ${ }^{9}$ as well as the American metaphysician David K. Lewis, styled the Leibniz of the twentieth century, because he reexamined the theory of possible worlds. This is a Lewis quotation:

It is our military capacities that matter, not our intentions. [...] Because our war plans are part of our capacities, even when they are not part of our intentions. ${ }^{10}$

Drawing on Lewis's metaphysics while departing from it, I was able to prove that this doctrine calls for a metaphysics of future where events necessarily occur: they cannot not

${ }^{8}$ This is translated into English with the phrase "Mutually Assured Destruction," whose acronym, MAD — which, taken as a word, literally means "insane" — came to designate deterrence itself.

9 "It is a curious paradox of our time that one of the foremost factors making deterrence really work and work well is the lurking fear that in some massive confrontation crisis it may fail. Under these circumstances one does not tempt fate." Bernard Brodie, War and Politics (New York: Macmillan, 1973), 370-371.

${ }^{10}$ David K. Lewis, "Finite Counterforce," in Nuclear Deterrence and Moral Restraint, ed. Henry Shue (Cambridge: Cambridge University Press, 1989), 67, 75. 
happen. ${ }^{11}$ This implies that the potential and the actual coincide. There is no difference between threatening one's enemy with launching an escalation that would wipe out one third of the world's population ${ }^{12}$ and actually doing so. Be warned, this is not a sociological theory à la Ivan Illich ${ }^{13}$ or à la Jacques Ellul, ${ }^{14}$ which would state that, once an implement - be it a deadly one - exists, it will inevitably be used. This is an ontological theory. In this case, any nuclear power possessing the means to kill a billion people has already, as it were, killed them, in this time where the future and the present communicate instantly, without going through the mediation of these mental acts that are intentions, plans, promises, and threats. Principle (3) in my previous presentation of the ethical paradox is no longer relevant. The opposition between (1) and (2) is frontal. Therefore, the rationality of nuclear deterrence can be "saved" in theory; but it must be concluded that, from a moral standpoint, it constitutes the abomination of desolation.

\section{Translated by Florina Haret}

\section{References}

Brodie, Bernard. War and Politics. New York: Macmillan, 1973.

Dupuy, Jean-Pierre. La Guerre qui ne peut pas avoir lieu. Essai de métaphysique nucléaire. Paris : Desclée de Brouwer, 2019.

_. "Le péril atomique et les raisons de notre insouciance." Préventique 166 (September 2019)

—. "The Nuclear Menace- A New Sacrament for Humanity: Catastrophes and Near Misses." In Apocalypse Deferred: Girard and Japan, edited by Jeremiah L. Alberg, 19-40. Notre Dame: University of Notre Dame Press, 2017.

—. Pour un catastrophisme éclairé. Paris : Seuil, 2004.

Ellul, Jacques. The Technological Society. New York: Vintage Books, 1964.

Illich, Ivan. Blasphemy: A Radical Critique of Our Technological Culture. Morristown: Aaron Press, 1995.

Kant, Immanuel. The Metaphysics of Morals, $2^{\text {nd }}$ edition. Cambridge: Cambridge University Press, 2017.

Kavka, Gregory. Moral Paradoxes of Nuclear Deterrence. Cambridge: Cambridge University Press, 2009.

Lewis, David K. “Finite Counterforce." In Nuclear Deterrence and Moral Restraint, edited by Henry Shue. Cambridge: Cambridge University Press, 1989.

Sagan, Scott D. "The Korean Missile Crisis. Why Deterrence is Still the Best Option.” Foreign Affairs (September 2017). https://www.foreignaffairs.com/articles/north-korea/201709-10/korean-missile-crisis (Accessed February 9, 2020).

The Fog of War: Eleven Lessons from the Life of Robert S. McNamara. Directed by Errol Morris. USA: Sony Pictures Classics, 2003.

\footnotetext{
11 See Jean-Pierre Dupuy, La Guerre qui ne peut pas avoir lieu. Essai de métaphysique nucléaire; Pour un catastrophisme éclairé (Paris : Seuil, 2004); "The Nuclear Menace- A New Sacrament for Humanity : Catastrophes and Near Misses," in Apocalypse Deferred : Girard and Japan, ed. Jeremiah L. Alberg (Notre Dame: University of Notre Dame Press, 2017), 19-40.

${ }_{12}^{12}$ ee Jean-Pierre Dupuy, "Le péril atomique et les raisons de notre insouciance" : 64, footnote 3.

13 See, for example, Ivan Illich, Blasphemy: A Radical Critique of Our Technological Culture (Morristown: Aaron Press, 1995).

${ }^{14}$ Jacques Ellul, The Technological Society (New York: Vintage Books, 1964).
} 